\title{
The Relationship between Teacher's Written Feedback and Student's' Writing Performance: Sociocultural Perspective
}

\author{
Maryam Bijami (Corresponding author) \\ School of Languages, Literacies, and Translation, Universiti Sains Malaysia, 11800 Penang, Malaysia \\ E-mail: MaryamBijami2013@yahoo.com \\ Ambigapathy Pandian \\ School of Languages, Literacies, and Translation, Universiti Sains Malaysia, 11800 Penang, Malaysia \\ E-mail: Ambiga@usm.my \\ Manjet Kaur Mehar Singh \\ School of Languages, Literacies, and Translation, Universiti Sains Malaysia, 11800 Penang, Malaysia \\ E-mail: manjeet@usm.my
}

Received: 12-11-2015

doi:10.7575/aiac.ijels.v.4n.1p.59
Accepted: 28-01-2016

URL: http://dx.doi.org/10.7575/aiac.ijels.v.4n.1p.59
Published: $31-01-2016$

\begin{abstract}
Feedback plays a fundamental role in writing development. The present study seeks to investigate the impact of teacher's written feedback on the writing performance of Iranian undergraduates. The subjects were 400 students majoring in the fields of English language translation and English language literature in four universities, namely Shahaid Bahonar, Vali-e-Asr, Isfahan and Shiraz, in Iran. Writing tasks, questionnaires and interviews were used in the process of the present study. Mixed methods research design was adopted in this study. Therefore, this research used the triangulation of data collection techniques. For data analysis, the thematic coding was used for analyzing semistructured interview. In the writing task, inter-rater agreement (Cohen kappa) was used and the Pearson correlation coefficient was run for analysis of the questionnaire. The result shows a significant relationship between teacher's written feedback and students' writing performance.
\end{abstract}

Keywords: Writing, Teacher feedback, Socio-cultural theory, English language

\section{Introduction}

The teacher has an important role in the facilitation of socialization in a child's life. When students go to school, they have a unique combination of family background, learning style, abilities, interest and the teachers come to school with certain abilities, teaching styles, ways of management and expectations. In the class environment, students and teachers communicate with each other which may enhance learning. In the process of socialization, the teacher provides the environment to facilitate learning. It must be noted that teachers in the class should be aware of students' needs, interests and abilities. Moreover, teachers should motivate students to be active in the learning process, consider the students' zone of proximal development, assist students to reach the independent level, and use collaborative activities to enhance learning. In fact, the teacher in this zone facilitates learning by guiding students and eliciting responses from them. So, it can be inferred that in this bidirectional activity both the teacher and students are engaged (Berns, 2007). The present study aims to investigate the relationship between teacher's feedback and writing performance of Iranian undergraduates majoring in English language translation and English language literature.

\subsection{Objective and Research Question}

The present study attempts to examine the effect of teachers' feedback on the writing performance of Iranian undergraduates who are majoring in English language translation and English language literature. Therefore, based on this objective, the present study is conducted to answer the following research question: To what extent does teachers' feedback affect the writing performance of Iranian undergraduates majoring in English language translation and English language literature?

\subsection{Teacher's Feedback and Sociocultural Theory}

Some researchers use sociocultural theory (SCT) to study written feedback (Aljaafreh \& Lantolf, 1994; Hyland \& Hyland, 2006; Murphy, 2000). Sociocultural feedback is a dialogic interaction that enables an expert who has knowledge (teacher) to prepare a context in which novices can participate in their own learning and in which the expert can fine-tune the support that the novices are given (Anton, 1999). 
The Zone of Proximal Development (ZPD) can be made when assisted (scaffolded) by a more advanced peer or teacher. Effective ZPDs make the student be responsible and be less dependent. Feedback, accordingly, is said to be mediating if it helps students to self-correct and move away from relying on the teacher (other regulation) towards relying on self to notice and initiate repairs (self-regulation) (Mustafa, 2012).

The central premise of feedback is that it is an essential factor in the writing context where the importance of feedback was highlighted with the development of "the process approach" to writing instruction. The process approach plays a high value on teacher-student encounters and stimulates teachers to shift the focus away from the final written product in an effort to support writers through multiple drafts by providing them with feedback during the process of writing. Its importance is also emphasized by genre-oriented approaches, where great focus is on sociocultural theories of scaffolded instruction and learning as a social practice. Here classroom situations and interactions, if pitched appropriately and meaningfully at learners' zones of proximal development, can help in diverse ways to scaffold people's acquisition of text forms, composing processes and purposeful social interactions through writing in the second language (Panahi, Birjandi, \& Azabdaftari, 2013).

\subsection{Teacher's Feedback and Writing}

Writing skill requires instruction from teachers who are qualified in their ability to help students to learn. Feedback is a social task which means that students are "historically and sociologically situated active agents who respond to what they see as valuable and useful and to people regard as engaging and credible" (Hyland \& Hyland, 2006, p.220). Some studies have shown the positive roles of teacher's feedback. These studies have focused on feedback on form (Ferris, 1995) and content (Fathman \& Whalley, 1990), others on different means of delivery (e.g. conferencing) (Goldstein \& Conrad, 1990).

It must be noted that in a writing class, a sophisticated teacher knows how to use feedback most effectively (Gielen, Tops, Dochy, Onghena, \& Smeets, 2010). Moreover, by giving feedback, students will be informed about the progress of their work (Noor et al., 2010). In the writing classroom, teacher's feedback can be instructive device to improve the teaching and learning of writing (Noor et al., 2010). Teacher written feedback on the students' writing indicates the problems and provides a good suggestion for improvement of future writing task, moreover, via feedback the teacher can help students to compare their writing with the ideal draft and recognize their own strength and weaknesses (Srichanyachon, 2012).

The shift of focus from writing as a product to writing as a process necessitates underlining multiple drafting of students' writing, which requires teachers to check and respond to these multiple drafts (Rahimi, 2009). A growing body of research has shown that students prefer teacher's feedback to non-teacher's feedback (e.g. peer feedback, selfassessment) (Chandler, 2003; Leki, 1990; Satio, 1994; Zang, 1995). The reason is that teacher's feedback is the easiest way for students to learn better. Chandler (2003) claims that the majority of students prefer the teacher checks and corrects their writing and feel that teacher's feedback by underlining the problem with description is the best way to learn not to repeat errors again in future. In addition, in a comparative study of peer and teacher feedback in a Chinese EFL writing class, Yang, Badger, and Yu (2006), examined two groups of students in writing essays on the same topic, one group was provided with teacher's feedback and another received feedback from their peer. The result of their study indicated that teacher's feedback led to improvements in the students' writing and peer feedback increased student autonomy. A growing body of literature has covered a wide perspective of the strategies that teachers utilize in giving feedback, and the effect of teacher's feedback on students' writing (Ferris \& Roberts, 2001; Hedgcock \& Lefkowitz, 1994; Lee, 2008; Srichanyachon, 2012; Zacharias, 2007).

\section{Methodology}

A total of 400 Iranian undergraduates majoring in the fields of English language translation and English language literature in the second semester of academic years 2014-2015 in four universities (Shahid Bahonar, Vali-e-Asr, Isfahan and Shiraz) in Iran participated in the present study. It must be noted that $150(37.5 \%)$ of the participants were males and $250(62.5 \%)$ were females. The total number of the participants in the field of English language literature was 228 $(57 \%)$ and $172(43 \%)$ in the field of English language translation. The participants were in their fifth to eight semester of their study and had already successfully passed English basic courses. It must be stated that non-probability sampling technique was administrated to select the required number of participants in this study. Moreover, the participants had passed courses related to writing such as: Grammar and Writing I, Grammar and Writing II, Advanced Writing, and Essay Writing. Therefore, they were qualified for participating in this research. Concurrent triangulation mixed method was adopted in the present study. The researchers conducted this study in two phases; first, quantitative phase which captures two types of data, namely writing task and questionnaire. In the second phase, qualitative data in the form of interview (semi-structured) was used to refine the results from quantitative data.

\subsection{Research Instruments}

Three research instruments, namely writing task, questionnaire and semi-structured interview were used in the process of the development of the present study. Thereby, this research benefited from the triangulation of data collection techniques.

\subsection{Writing Task}

The writing task was the first instrument administrated to the sample. The participants were instructed to write welldesigned essays. Three different topics were introduced to the participants who were free to choose one topic to write 
about. These three topics were chosen from one of the writing books taught in Shahid Bahonar University. An essay outline adopted from Mackenzie (2007) was given to the participants as a guide to write essays. Participants were asked to write at least 3 paragraphs. As for the assessment procedure of written output, two raters were invited to participate in the study. Before scoring the participants' papers, the aim of assessment and design of study were explained to the two raters by the researcher. They were asked to assess all essays based on the holistic scoring rubric by Thompson (2009).

2.3 Questionnaire

The second instrument in this study was a questionnaire. The questionnaire contained closed-ended questions and was adapted from Goldburg, (2012); Jumu'ah, (2009) and Mahfoodh, (2011).The number of questionnaire items was 11. Moreover, the respondents were asked to identify the extent to which they agree or disagree with 5-point scale Likert style items by circling one of the responses from "strongly agree" to "strongly disagree".

\subsection{Semi-Structured Interview}

The third instrument utilized in this study was a semi-structured interview. At first, for content validity, the interview questions were reviewed by two lecturers who had $\mathrm{PhD}$ degrees in English language translation. They checked drafts of questions to assess whether the items met the study objectives or not. After questionnaires had been administrated, the students were asked to write their contact numbers if they agree to participate for interview. A total 40 students volunteered for the semi-structured interview. When the interview was scheduled; the time and place of interview were established. Before starting the interview the participants were briefed on its purpose. The participants' responses were recorded and transcribed one-by-one by the researchers. It must be noted that the thematic coding analysis was adopted for analyzing the semi-structured interview. This type of analysis consists of two directions namely, horizontally and vertically. In horizontal direction each single raw shows an overview of a particular person's statement. In the vertical direction, each column gives a topic-oriented perspective. The interview of each participant took 20-25 minutes approximately.

\section{Results}

In the present study, the participants' writing task was rated holistically by two raters. In order to measure the agreement between two raters, inter-rater reliability agreement (Cohen's Kappa) was run. As Table 1 shows, $\mathrm{K}=.837, p=.000$, which means there is strong agreement between two raters in scoring participants' writing task.

Table 1. Inter-Rater Reliability between Raters

\begin{tabular}{lcccc}
\hline & Value & $\begin{array}{c}\text { Asymp.Std. } \\
\text { Error }^{\mathrm{a}}\end{array}$ & Approx. T $^{\mathrm{b}}$ & $\begin{array}{c}\text { Approx. } \\
\text { Sig. }\end{array}$ \\
\hline $\begin{array}{l}\text { Measure of Agreement Kappa } \\
\text { N. of Valid Cases }\end{array}$ & $\begin{array}{c}.837 \\
400\end{array}$ & .5 & 23.359 & .000 \\
\hline
\end{tabular}

Moreover, Cronbach's alpha was run to measure the internal consistency of question items related to teacher's feedback. Table 2 indicates the high level of internal consistency reliability $(\alpha=.818)$ which is higher values than the minimum accepted value of 0.70 .

Table 2. The Internal Reliability Test Result of Teacher's Feedback Questionnaire Items

\begin{tabular}{ccc}
\hline Cronbach's Alpha & Cronbach's Alpha based on Standardized Items & No. of Items \\
\hline .818 & .820 & 11 \\
\hline
\end{tabular}

In the next step, Pearson correlation coefficient was run to measure the relationship between teacher's feedback and students' writing performance. As Table 3 shows, the correlation coefficient between teacher's feedback and participants' writing performance was $\mathrm{r}=0.117, \mathrm{n}=400, p=.019$, which shows the weak relationship between these two variables but it is significant $(p<0.05)$.

Table 3. Correlation Coefficient between Teacher's Feedback and Students' Writing Score

\begin{tabular}{llcc}
\hline & & $\begin{array}{c}\text { Final writing } \\
\text { score }\end{array}$ & $\begin{array}{c}\text { Teachers' } \\
\text { feedback }\end{array}$ \\
\hline Final writing score & Pearson Correlation & 1 & .117 \\
& p-value (2-tailed) & & .019 \\
& $\mathrm{~N}$ & 400 & 400 \\
\hline
\end{tabular}

In the case of second phase of conducting the present study, it must be mentioned that the grounded theory was adopted for qualitative data analysis. This theory deals with codes and categories (Kuckartz, 2014). After the participants' responses were collected, the researcher assigned categories and created codes for selective themes. It must be noted 
that two codes (positive and negative) specify teacher's feedback. Two codes, namely positive and negative were used as yes or no answers. Table 4 displays coding system for teacher's feedback.

Table 4. Coding System for Teacher's Feedback

\begin{tabular}{llll}
\hline Topic & Categories & Code & Description \\
\hline \multirow{2}{*}{ Teachers' } & 1) Teachers' Feedback & -PETF & - Positive Effect of Teacher's Feedback \\
Feedback & 2)Direct Feedback & -NETF & - Negative Effect of Teacher's Feedback \\
& & -PEDF & - Positive Effect of Direct Feedback \\
& -NEDF & - Negative Effect of Direct Feedback \\
& 3) Indirect Feedback & -PEIF & - Positive Effect of Indirect Feedback \\
& 4)Teachers' Conferencing & -NEIF & - Negative Effect of Indirect Feedback \\
& -NETC & - Positive Effect of Teacher's \\
& & Conferencing \\
& & -Negative Effect of Teacher's \\
& & Conferencing \\
\hline
\end{tabular}

The code PETF (Positive Effect of Teacher's Feedback) shows that teacher's feedback had a positive effect on participants' writing. The code NETF (Negative Effect of Teacher's Feedback) was used to show the negative influence of the teacher's feedback. It means that some participants believed that teacher's feedback has no positive effect on their writing performances. Moreover, the code PEDF (Positive Effect of Direct Feedback) was used to indicate that the participants expressed their willingness to get direct feedback on their writing class, and they found that direct feedback is a useful feedback on their writing performance. Conversely, NEDF (Negative Effect on Direct Feedback) shows the negative effect of direct feedback. Moreover, some participants believed that indirect feedback has a positive effect on their writing performance and, others believed that it has negative effect on their writing performance. Therefore, two codes were used to explain this type of feedback, namely PEIF (Positive Effect of Indirect Feedback) and NEIF (Negative Effect of Indirect Feedback).

It must be noted that the codes PETC and NETC specify positive effect of teacher's conferencing and negative effect of teacher's conferencing, respectively. In this regard, some participants had positive experiences in conferencing with their teacher. Others had no experience in this activity. Table 5 presents the thematic category for teacher's feedback in the present study.

Writing Improvement: With regard to the idea if the teachers' feedback has a positive effect on participants' writing performance, approximately all of participants answered yes. They mentioned that after getting teacher's feedback on their writing, they recognised that their writing performance was significantly improved.

P2: (Participant Number 2)

...Teacher's feedback is very useful for students to improve their writing's performance. In English writing classes in the university, lecturers revised our writing draft and gave feedback to us. Therefore, my writing significantly improved a lotin previous semesters.

P6: (Participant Number 6)

...I received teacher's feedback in my writing classroom in previous semester. It was very useful for me. I actually got valuable comments from teacher's feedback and my writing performance was significantly improved.

Table 5. The Thematic Category for Teachers' Feedback

\begin{tabular}{|c|c|c|}
\hline Topic & Codes & Selective Themes \\
\hline \multirow{8}{*}{ Teachers' Feedback } & -PETF & -Writing Improvement \\
\hline & -NETE & -No Writing Improvement \\
\hline & -PEDF & $\begin{array}{l}\text {-Better Understanding } \\
\text {-Time Saving }\end{array}$ \\
\hline & -NEDF & $\begin{array}{l}\text {-More Independent } \\
\text {-No Writing Improvement }\end{array}$ \\
\hline & -PEIF & $\begin{array}{l}\text {-Independent } \\
\text {-More Learning }\end{array}$ \\
\hline & -NEIF & $\begin{array}{l}\text {-Time Wasting } \\
\text {-No Understanding }\end{array}$ \\
\hline & -PETC & $\begin{array}{l}\text {-Writing Improvement } \\
\text {-Discussion about Writing }\end{array}$ \\
\hline & -NETC-No & -Experience \\
\hline
\end{tabular}


Better Understanding and Time Saving: To deal with the question which kind of comments on their writing from the teacher the participants found most helpful for their writing, some participants reported that direct feedback was the most helpful for their writing. In direct feedback, teachers underline errors on writing and write down the correct form. Participants also stated that, they got a better understanding of their errors on writing as a result of getting direct feedback. In this regard, the teacher corrects their errors, therefore; students can save their time correcting their errors by themselves.

\section{P3: (Participant Number 3)}

... I got direct feedback during my English language writing class. I think direct feedback is very useful. The reason is that in direct feedback, teacher underlines the errors and writes the correct form of errors. Therefore, we understand better. In addition, it is necessary for us to search and determine the correct form and revise our draft. In fact, we save our time and, thus we can spend more time studying.

More Dependent and No Improvement: Most students believed that direct feedback makes students depend on teachers; especially they become more passive because teachers underline all errors and then correct the errors for students.

P9: (Participants Number 9):

... For me, direct feedback makes students to be more dependent on their teachers. Therefore, students cannot determine the reason why they had problem with some parts of their writing. For me, it is better to let students identifying their own errors so that they could get more experiences in errors they made. Teachers underline wrong grammatical structures and then provide the correct forms for students.

Independent and More Learning: The majority of participants mentioned that they got indirect feedback in their English writing class. They believed that indirect feedback is more helpful than direct feedback. It is because they could learn better when they themselves are responsible for determining correct grammatical structures or errors that they made in their writing drafts. They said that getting indirect feedback from teacher makes them to become more independent.

\section{P7: (Participant Number 7)}

... I got both direct feedback and indirect feedback during my English writing course classes. For me, the most helpful feedback was indirect feedback. The reason was that from indirect feedback, the teacher did not correct our errors. He only underlined the errors in the draft and asked us to revise and determine the reasons why our errors were made. It was useful for me because I could significantly improve my English language from indirect feedback. In fact, I attempted to study to determine my problem faced in my writing. Moreover, I did not depend on my teacher.

Time Wasting and No Understanding: Although most participants noted that indirect feedback was useful for them; however, few mentioned that indirect feedback was not useful in writing class. They interpreted that in indirect feedback, students themselves could determine the reason why they made mistakes or errors and write down the correct form. They also said that sometimes, they might make mistakes or errors; however, they did not understand why they made those errors or mistakes and could not find the correct form which makes them waste their time.

\section{P5: (Participant Number 5)}

...I received indirect feedback during my writing class in previous semesters. However, I was dissatisfied with this kind of feedback because my teacher just underlined some words and sentences to show our errors, but he did not correct them. I myself sometimes did not understand why I made my errors. It therefore, took time for me to find the reason why I made my errors as well as I did not know how to correct those errors.

Writing Improvement and Discussion about Writing: Regarding the question if the participants had teacher-student conferencing, and if they said "yes", did they find it useful for their writing or not, the majority of participants said that they had conferencing in their English writing class. They also stated that this kind of feedback had a positive effect on their writing performance. Moreover, during the conferencing, they could discuss with their teachers about their writing.

\section{P4: (Participant Number 4)}

...In advanced writing course, my teacher used this feedback in the class. I was satisfied with this feedback. The reason was that in conferencing feedback, teacher discussed directly with us and explained about the errors in the writing. Moreover, this feedback enhanced the relationship and improved oral communication between the teacher and students. Sometimes, I hesitated to discuss with my teacher about my errors and my writing assignment, nevertheless by using this kind of feedback, I could discuss with teacher and felt relaxed with him. In my opinion, conferencing really had a positive impact on my writing performance.

No experience: Among participants few participants mentioned that they had no teacher-student conferencing experience in their English writing class.

\section{P8: (Participant Number 8)}

... In English writing class in the university, I had no experience in teacher-student conferencing. Our English writing lecturers never used this kind of feedback in the writing classroom. 


\section{Discussion and Conclusion}

The finding of this study supports the results of previous studies suggesting the positive effect of teacher's feedback on students' writing performance (Hyland \& Hyland, 2006; Mahfoodh \& Pandian, 2011; Srichanyachon, 2012). Rahimi and Gheitasi (2010), asserted that providing feedback and responding to students' writing is a significant area of teachers' work. Indeed, teacher indicates students' writing problem and provides comments for improvement of future writing comments. Moreover, through feedback, teacher assists students to recognise their weaknesses and strengths (Srichanyachon, 2012).

In the present study, the qualitative findings explored participants' perspectives on having teachers' feedback in their English writing class at university. They claimed that after getting feedback on their writing, they recognised that their writing performance has significantly improved. This finding is valuable because it shows that teacher can be a fundamental source in improving students' writing. Indeed, teacher plays a critical role in students' writing skill. Moreover, students reported that different kinds of feedback such as: a) direct feedback, b) indirect feedback and c) teacher-student conferencing.

According to the students, they got a better understanding of their errors on their writing as a result of getting direct feedback. Indeed, this type of feedback is suitable for low proficiency students who are not able to self-correct of error (Eslami, 2014). To deal with indirect feedback, majority of students mentioned that they learned better when they were responsible for determining errors that they made in their writing draft. They believed that they become more independent by getting indirect feedback and understood better. This claim has been supported by Ferris and Roberts (2001) which mentioned that indirect feedback is useful strategy which leads to long-term learning.

This study also confirmed that teacher-student conferencing was one of the factors which played cardinal role in improving students' writing performance. Conference provides students with opportunities for negotiation and interaction with their teachers which normal classroom activities do not provide (Bultron, 2014). This is because of limited time and a large number of students in the class. As the results showed, students were satisfied with this activity. They reported that in teacher-students conferencing they discussed with teacher about their writing errors or mistakes directly. Students mentioned that by discussing with teacher in conferencing, they got engaged more in writing process and learned better. Moreover, Hyland and Hyland (2006) claimed that face-to-face conferencing provides strong relationship between teacher and students which influences students writing.

The main thing that teacher needs to pay attention is that, different students learn differently. Research on learning styles (Oxford, 1990) has indicated that people learn in different ways. Some students are mainly auditory rather than visual learners. In other words, these learners learn better by listening than by reading. So these learners might learn best if the teacher gives oral feedback through a conference, instead of written comments on the students' writing draft (Bultron, 2014). Therefore, in this case conferencing can be the best method in writing class.

In the writing classroom, teacher's feedback is a good instructive tool to promote teaching and learning of writing (Rahimi \& Gheitasi, 2010). Students learn better when teacher gives comments on their writing (e.g. direct feedback, indirect feedback \& teacher-student conferencing feedback). In fact, through feedback teacher can assist students to compare their drafts with the ideal draft and recognise their own strengths and weaknesses (Srichanyachon, 2012).

\section{References}

Adair-Hauck, B., \& Donato, R. (1994). Foreign language explanations within the zone of proximal development. Canadian Modern Language Review, 50, 532-557.

Aljaafreh, A., \& Lantolf, J. P. (1994). Negative feedback as regulation and second language learning in the zone of proximal development. The Modern Language Journal, 78(4), 465-483. DOI: 10.1111/j.1540-4781.1994.tb02064.x

Anton, M. (1999). The discourse of a learner-centered classroom: Sociocultural perspectives on teacher-learner interaction in the second-language classroom. The Modern Language Journal, 83(3), 303-318. DOI: 10.1111/00267902.00024 .

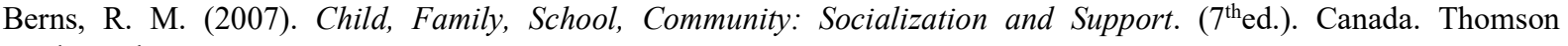
Wadsworth.

Bultron, A. L. (2014). The use of teacher-written feedback and computer mediated feedback to enhance Puerto Rican English as a second language (ESL) high school students' essay writing (Published PhD Thesis). Universid ad Del Turabo.

Chandler, J. (2003). The efficacy of various kinds of error feedback for improvement in the accuracy and fluency of L2 student writing. Journal of Second Language Writing, 12(3), 267-96. DOI:10.1016/S1060-3743(03)00038-9

Eslami, E. (2014). The effects of direct and indirect corrective feedback techniques on EFL students' writing. International Conference on Current Trends in ELT. Procedia-Socail and Behavioral Sciences, 98, 445-452. DOI:10.1016/j.sbspro.2014.03.438. 
Ferris, D. R. (1995). Student reactions to teacher response in multiple-draft classrooms. TESOL Quarterly, 29(1), 3353.

Ferris, D. \& B. Roberts (2001). Error feedback in L2 writing classes: How explicit does it need to be? Journal of Second Language Writing 10(3), 161-184. DOI:10.1016/S1060-3743(01)00039-X.

Gielen, S., Tops, L., Dochy, F., Onghena, P., \& Smeets, S. (2010). A comparative study of peer and teacher feedback and of various peer feedback forms in a secondary school writing curriculum. British Educational Research Journal, 36(1), 143-162. DOI: 10.1080/01411920902894070.

Goldburg, M. E. (2012). ESL students' perceptions of their English writing proficiency and the effects of peer review training among their types of students in a community college ESL composition course (Published PhD Thesis). Alliant International University. San Diego.

Goldstein, L. M, \& Conrad, Susan, M. (1990). Student Input and Negotiation of Meaning in ESL Writing Conferences. TESOL Quarterly, 24, 443-460.

Hedgcock, J. S., \& Lefkowitz, N. (1994). Feedback on feedback: Assessing learner receptivity in second language writing. Journal of Second Language Writing, 3(2), 141-163.

Hyland, K. \& Hyland, F. (2006). Contexts and issues in feedback on L2 writing: An introduction. In K. Hyland \& F. Hyland (Eds.) Feedback in Second Language Writing: Contexts and Issues (pp. 1-19). New York: Cambridge University Press.

Jumu'ah, B. (2009). The effect of parental involvement on student achievement at Hillside High School Twilight Academy (Published PhD Thesis). University of Phoenix. USA.

Kuckartz, U. (2014). Qualitative Text Analysis: A Guide to Methods, Practice and Using Software. London: SAGE Publications Ltd.

Lee, I. (2008). Students' reactions to teacher feedback in two Hong Kong secondary classrooms. Journal of Second Language Writing, 17(3), 144-164. DOI:10.1016/j.jslw.2007.12.001.

Leki, I. (1990). Potential problems with peer responding in ESL writing classes. CATESOL Journal, 3, 5-17.

Mahfoodh, O. H. A. (2011). Teacher written feedback in EFL Yemen context: A qualitative case study of students' reactions and utilizations (Unpublished $\mathrm{PhD}$ Thesis). University Sains Malaysia. Malaysia.

Mahfoodh, O. H. H., \& Pandian, A. (2011). A qualitative case study of EFL students' affective reactions to and perceptions of their teachers' written feedback. English Language Teaching Journal, 4(3), 14-25. DOI: http://dx.doi.org/10.5539/elt.v4n3p14.

Murphy, S. (2000). A sociocultural perspective on teacher response: Is there a student in the room? Assessing Writing 7(1), 79-90. DOI:10.1016/S1075-2935(00)00019-2.

Mustafa, R. F. (2012). Feedback on the feedback: Sociocultural interpretation of Saudi ESL learners' opinions about writing feedback. English Language Teaching. 5(3), 3-15. DOI: http://dx.doi.org/10.5539/elt.v5n3p3.

Noor, N. M., Aman, I., Mustaffa, R., \& Seong, T. K. (2010). Teacher's verbal feedback on students' response: A Malaysian ESL classroom discourse analysis. Procedia-Social and Behavioral Sciences, 7, 398-405. DOI:10.1016/j.sbspro.2010.10.054

Oxford, R.L. (1990). Language Learning Strategies: What Early Teacher Should Know. Boston: Heinle \& Heinle.

Panahi, P., Birjandi, P., \& Azabdatari, B. (2013). Towards a sociocultural approach to feedback provision in L2 writing classrooms: the alignment of dynamic assessment and teacher error feedback. Language Testing in Asia, 3(13), 1-10. DOI:10.1186/2229-0443-3-13.

Rahimi, M. (2009). The role of teachers' corrective feedback in improving Iranian EFL learners' writing accuracy overtime: is learners' mother tongue relevant? Read and Writing, 22, 219-243. DOI: 10.1007/s11145-008-9139-5.

Rahimi, A. \& Gheitasi, P. (2010). The interface between English teachers' sense of efficacy and their feedback on learners' writing, and learners' writing achievement. Procedia Social and behavioral Sciences, 5, 1932-1938. DOI:10.1016/j.sbspro.2010.07.391.

Saito, H. (1994). Teachers' practices and students' preferences for feedback on second language writing: A case study of adult ESL learners. TESL Canada Journal, 11, 46-70.

Srichanyachon, N. (2012). Teacher written feedback for L2 learners' writing development. Silpakorn University Journal of Social Sciences, Humanities and Arts, 12(1), 7-17.

Thompson, C. L. (2009). The effect of writing evaluation on writing performance: A study in writing proficiency levels of fifth grade students (Published $\mathrm{PhD}$ Thesis).Tennessee State University. USA. 
Yang, M., Badger, R., \& Yu, Z. (2006). A comparative study of peer and teacher feedback in a Chinese EFL writing class. Journal of Second Language Writing, 15(3), 179-200. DOI:10.1016/j.jslw.2006.09.004.

Zacharias, N. T. (2007). Teacher and student attitudes toward teacher feedback. RELC Journal: A Journal of Language Teaching and Research, 38(1), 38-52. DOI: 10.1177/0033688206076157.

Zhang, S. (1995). Re-examining the affective advantages of peer feedback in the ESL writing classroom. Journal of Second Language Writing, 4(3), 209-222. DOI:10.1016/1060-3743(95)90010-1. 